\title{
ALKALINE PROTEASE PRODUCTION BY Bacillus licheniformis LBA 46 IN A BENCH REACTOR: EFFECT OF TEMPERATURE AND AGITATION
}

\author{
Jessika G. dos S. Aguilar ${ }^{1 *}$, Ruann J. S. de Castro $^{1}$ and Hélia H. Sato ${ }^{1}$ \\ ${ }^{1}$ Universidade de Campinas, Faculdade de Engenharia de Alimentos, Departamento de Ciência de Alimentos, Campinas, SP, Brasil. \\ E-mail: jessgsantos@gmail.com - ORCID: 0000-0003-4435-7565; ORCID: 0000-0003-2649-8567; ORCID: 0000-0002-8170-7088
}

(Submitted: January 11, 2018 ; Revised: September 17, 2018 ; Accepted: September 21, 2018)

\begin{abstract}
The production of protease from Bacillus licheniformis LBA 46 was studied in a 6 L reactor using the experimental design tool. The higher protease production was obtained in the exponential phase of growth reaching maximum activity $(\sim 3,000 \mathrm{U} / \mathrm{mL})$ after $48 \mathrm{~h}$ of fermentation at $30^{\circ} \mathrm{C}$ and $300 \mathrm{rpm}$ in a culture medium made of agroindustrial by-products. In the thermostability study, the semi-purified enzyme retained about $78 \%$ of the initial activity after $120 \mathrm{~min}$ at $50{ }^{\circ} \mathrm{C}$. The protease was purified 3.33 times by ammonium sulfate precipitation and DEAE-Sepharose column chromatography and had a molecular mass estimated at $40 \mathrm{kDa}$ by SDS-PAGE. The purified protease showed optimum activity at 50 and $60{ }^{\circ} \mathrm{C}$, optimal activity in $\mathrm{pH} 8.5$ and stability in the range between $\mathrm{pH} 5-10$ after $24 \mathrm{~h}$ of incubation at $4{ }^{\circ} \mathrm{C}$, presenting more than $86 \%$ of the initial activity.

Keywords: Bacillus licheniformis; Fermentation; Optimization; Protease; Purification.
\end{abstract}

\section{INTRODUCTION}

Industries of food, pharmaceutical, agricultural and medical have been taking advantage of using Bacillus sp. because of their wide range of physiological characteristics and ability to produce enzymes and other metabolites (Gupta et al. 2002; Schallmey et al. 2004; Voigt et al., 2004). Bacillus subtilis and Bacillus licheniformis species are attractive industrial microorganisms recognized as GRAS (generally recognized as safe), which have high growth rates leading to shorter fermentation times and posses the ability to secrete extracellular proteins (Ward et al. 2009; Ward 2011; Parrado et al. 2014).

Since the advent of enzymology, one of the most important classes of hydrolytic enzymes, which have been extensively studied, is the microbial proteases (Furhan and Sharma 2014; Hadjidj et al. 2018). Each enzyme has a peculiar characteristic of performance, which makes it suitable for several applications. The alkaline proteases were initially marketed for use in detergents and the market for these industrial enzymes expanded substantially during the 1960s. Until nowadays they are one of the most widely studied groups of enzymes because of their extensive types of application in several sectors such as detergent, textile, leather and food industries (Benmrad et al. 2016; Bouacem et al. 2016; Ward et al. 2009). The main microbial strains used in enzyme production are still Bacillus species, used principally to produce alkaline serine proteases and neutral proteases (Schallmey et al. 2004; Ward 2011; Pant et al. 2015).

On an industrial scale, microorganisms are cultivated in reactors under the best conditions of production (Moo-Young and Chisti 1994; Gupta et al. 2002). According to Potumarthi et al. (2007), mixing in the reactor is important during the production of proteases, which is transmitted by aeration and agitation. The temperature is another important function to control in a fermentative process, so

\footnotetext{
*Corresponding author: Jessika G. dos S. Aguilar - E-mail: jessgsantos@gmail.com
} 
there is a necessity of defining a better combination of these factors within the fermentation process for maximum efficiency and productivity. Based on this, the aim of this study was to verify the effects of modifying temperature and agitation conditions during the submerged fermentation of $B$. licheniformis LBA 46 in a reactor on protease production, using the experimental design process.

\section{MATERIALS AND METHODS}

\section{Fermentation}

\section{Microorganism and culture medium}

The microorganism used was a strain of $B$. licheniformis LBA 46 from the culture collection of the Laboratory of Food Biochemistry, School of Food Engineering, UNICAMP, Brazil. The culture medium used was proposed by Contesini (2014), with modifications, containing agroindustrial by-products as carbon and nitrogen sources $(32 \mathrm{~g} / \mathrm{L}$ of sugar cane molasses (Fio de Ouro ${ }^{\circledR}$ ); $6 \mathrm{~g} / \mathrm{L}$ of corn steep liquor (Corn Products $^{\circledR}$ ); 2 g/L of yeast extract (Prodex-Lac $\mathrm{SD}^{\circledR}$ ) and 20 of $\mathrm{g} / \mathrm{L}$ dried whey $\left(\right.$ Alibra $\left.^{\circledR}\right)$, adjusted to $\mathrm{pH}$ 7).

\section{Inoculum preparation}

The microorganism was grown in nutrient agar (1 g/L of meat extract; $2 \mathrm{~g} / \mathrm{L}$ of yeast extract; $5 \mathrm{~g} / \mathrm{L}$ of peptone; $5 \mathrm{~g} / \mathrm{L}$ of sodium chloride and $15 \mathrm{~g} / \mathrm{L}$ of agar, pH 7) slants and incubated at $30{ }^{\circ} \mathrm{C}$ for $18-24 \mathrm{~h}$. After growth, a bacterial cell suspension was prepared by adjusting the absorbance at $620 \mathrm{\eta m}$ to $0.49-0.51$. Erlenmeyer flasks containing the cell suspension and culture medium were incubated at $30{ }^{\circ} \mathrm{C}$ and $200 \mathrm{rpm}$ for 36-40 h.

\section{Submerged fermentation in a reactor}

The fermentation of $B$. licheniformis LBA 46 was performed in a New Brunswich Bioflo II reactor with a capacity for $6 \mathrm{~L}$ and a working volume of $3 \mathrm{~L}$. The inoculum represented $10 \%$ of the culture medium and was prepared as described above. Foaming was controlled during fermentation using the antifoam DC*FG-10 (Dow Corning ${ }^{\circledR}$ ), which dripped automatically when the foam level reached the sensor. The air flow rate was maintained at $0.8 \mathrm{vvm}$. The $\mathrm{pH}$ value was monitored using a calibrated potentiometer. The total fermentation time was $72 \mathrm{~h}$, and samples $(15 \mathrm{~mL})$ were collected every $12 \mathrm{~h}$ and centrifuged at $11,000 \times \mathrm{g}$ for $15 \mathrm{~min}$ at $5^{\circ} \mathrm{C}$. The cell-free supernatant was used as the enzyme extract for determination of protease activity.

\section{Optimization of temperature and agitation}

A factorial design with 4 possible combinations and 3 central points was used to optimize and evaluate the effects of temperature and agitation for the reactor fermentation, resulting in a total of 7 tests, which were carried out in random order. Table 1 shows the coded and real values of the variables studied.

Table 1. Factorial design, coded and real values of the variables studied (temperature and agitation).

\begin{tabular}{crc}
\hline Assay & $\begin{array}{c}\mathbf{T} \\
\left({ }^{\circ} \mathbf{C}\right)\end{array}$ & $\begin{array}{c}\text { Agitation } \\
(\mathbf{r p m})\end{array}$ \\
\hline 1 & $-1(30.0)$ & $-1(200)$ \\
2 & $1(37.0)$ & $-1(200)$ \\
3 & $-1(30.0)$ & $1(300)$ \\
4 & $1(37.0)$ & $1(300)$ \\
5 & $0(33.5)$ & $0(250)$ \\
6 & $0(33.5)$ & $0(250)$ \\
7 & $0(33.5)$ & $0(250)$ \\
\hline
\end{tabular}

Kinetics of microbial growth and protease production

The microbial growth kinetics of $B$. licheniformis LBA 46 and the protease production were carried out in a $6 \mathrm{~L}$ reactor containing $3 \mathrm{~L}$ composed of $32 \mathrm{~g} / \mathrm{L}$ of sugar cane molasses (Fios de Ouro $\left.{ }^{\circledR}\right) ; 6 \mathrm{~g} / \mathrm{L}$ of corn steep liquor (Corn Products ${ }^{\circledR}$ ); $2 \mathrm{~g} / \mathrm{L}$ of yeast extract (Prodex-Lac SD ${ }^{\circledR}$ ) and $20 \mathrm{~g} / \mathrm{L}$ dried whey (Alibra ${ }^{\circledR}$ ), adjusted to $\mathrm{pH} \mathrm{7}$, at $300 \mathrm{rpm}, 30{ }^{\circ} \mathrm{C}$ and $0.8 \mathrm{vvm}$. Samples of the culture media were collected at different times and inoculated into Petri dishes containing nutrient agar using the pour plate technique. Petri dishes were incubated at $30{ }^{\circ} \mathrm{C}$ for $24 \mathrm{~h}$. Microbial growth was expressed as colony forming units (CFU)/ $\mathrm{mL}$. Protease activity, protein and reducing sugar were determined as described below.

\section{Protease activity determination}

Protease activity was determined according to the method described by Charney and Tomarelli (1947) and modified by Castro and Sato (2014), using azocasein as the substrate. The reaction mixture contained 0.5 $\mathrm{mL}$ of $0.5 \%$ azocasein in $0.05 \mathrm{M}$ sodium phosphate buffer, $\mathrm{pH} 7$, and $0.5 \mathrm{~mL}$ of the enzymatic extract which were incubated for $40 \mathrm{~min}$ at $60{ }^{\circ} \mathrm{C}$. The reaction was stopped by adding $0.5 \mathrm{~mL}$ of $10 \%$ trichloroacetic acid (TCA). The reaction mixture was centrifuged at $17,000 \times \mathrm{g}$ for $15 \mathrm{~min}$ at $15^{\circ} \mathrm{C}$. An aliquot of $1 \mathrm{~mL}$ of the supernatant obtained was neutralized with $1 \mathrm{~mL}$ of $5 \mathrm{M} \mathrm{KOH}$. One protease activity unit was defined as the amount of enzyme which caused an increase of 0.01 in absorbance at $428 \eta \mathrm{m}$.

\section{Protein and reducing sugar determination}

Protein quantification was carried out by Lowry's method with some modifications (Hartree, 1972). The calculations were based on a standard curve of bovine serum albumin (BSA) and were expressed in $\mathrm{mg} / \mathrm{mL}$. The reducing sugars were quantified with dinitrosalicylic acid, DNS (Miller, 1959). The calculations were based on a standard glucose curve and were expressed in $\mathrm{mg} / \mathrm{mL}$. 
Determination of kinetic and thermodynamic parameters of semi-purified protease

Activation energy and temperature coefficient $\left(Q_{10}\right)$

To determine the activation energy $\left(E_{a}\right)$, measurements of protease activity were performed with incubation at different temperatures, $30-80{ }^{\circ} \mathrm{C} . E_{a}$ was calculated from the slope of the plot of $1000 / \mathrm{T}$ vs. $\ln$ (protease activity), $E_{a}=$ - slope $\mathrm{x}$ R.

The value of the temperature coefficient, $Q_{10}$, was determined according to Eq. 1 (Dixon and Webb, 1979). This measure is used to relate the reaction rate with a $10{ }^{\circ} \mathrm{C}$ increase in the reaction temperature.

$\mathrm{Q}_{10}=\operatorname{antilog} \varepsilon\left(\frac{\mathrm{E}_{\mathrm{a}} \times 10}{\mathrm{RT}^{2}}\right)$

where $\mathrm{R}$ is the gas constant $(8.314 \mathrm{~J} / \mathrm{Kmol})$ and $\mathrm{T}$ is the absolute temperature $(\mathrm{K})$.

\section{Determination of $K_{m}$ and $V_{m}$}

Kinetic parameters (Michaelis Mentem constants, $K_{m}$ and maximum velocity, $V_{\text {max }}$ ) were determined at the optimal temperature and $\mathrm{pH}$ of protease activity using different concentrations of azocasein as substrate $(1-10 \mathrm{mg} / \mathrm{mL})$.

Determination of kinetic and thermodynamic parameters for thermal inactivation

Kinetic parameters for thermal inactivation - To determine the thermal inactivation of the protease, the enzyme was incubated in $0.05 \mathrm{M}$ sodium phosphate buffer, $\mathrm{pH} 7$, at temperatures of $50-70{ }^{\circ} \mathrm{C}$ for $120 \mathrm{~min}$ in the absence of substrate. Samples were collected periodically throughout the incubation period and residual activity was determined at the optimal temperature and $\mathrm{pH}$ of protease activity.

The value of the deactivation constant $\left(k_{d}\right)$ expressed as an exponential decay and found by plotting $\ln (A /$ $\left.A_{0}\right)$ vs. time was measured according to Eq. 2.

$$
\mathrm{A}=\mathrm{A}_{0} \mathrm{e}^{-\mathrm{k}_{\mathrm{d}} \mathrm{t}}
$$

where $A$ and $A_{0}$ is the protease activity at a determined time $t$ and at an initial time, respectively.

The activation energies for denaturation $\left(E_{a d}\right)$ were calculated by plotting $\ln \left(k_{d}\right)$ vs. 1/RT as described in Eq. 3. The time when the residual activity reaches $50 \%$ (apparent half-life) was estimated by Eq. 4 . The $D$-value, which is defined as the time required for a $90 \%$ reduction in the initial enzyme activity at a specific temperature, was calculated as shown in Eq. 5.

$$
\begin{aligned}
& \mathrm{k}_{\mathrm{d}}=A \mathrm{e}^{\left(\frac{-\mathrm{E}_{\mathrm{ad}}}{\mathrm{RT}}\right)} \\
& \mathrm{t}_{1 / 2}=\frac{\ln (0.5)}{\mathrm{k}_{\mathrm{d}}}
\end{aligned}
$$

$\mathrm{D}=\frac{2.303}{\mathrm{k}_{\mathrm{d}}}$

Thermodynamic parameters for thermal inactivation - Thermodynamic parameters of the protease were projected using the Eyring absolute rate expression (Eq. 6).

$\mathrm{k}_{\mathrm{d}}=\left(\frac{\mathrm{k}_{\mathrm{b}} \mathrm{T}}{\mathrm{h}}\right) \mathrm{e}^{\left(\frac{-\Delta \mathrm{H}}{\mathrm{RT}}\right)} \mathrm{e}^{\left(\frac{\Delta \mathrm{S}}{\mathrm{R}}\right)}$

where $k_{b}$ is the Boltzmann constant $\left(1.38 \times 10^{-23} \mathrm{~J} / \mathrm{K}\right) ; \mathrm{T}$ is the absolute temperature (K); $\mathrm{h}$ is the Planck constant $\left(6.63 \times 10^{-34} \mathrm{~J} . \mathrm{s}\right) ; \Delta \mathrm{H}$ is the enthalpy of activation $(\mathrm{kJ} /$ $\mathrm{mol})$ and $\Delta \mathrm{S}$ is the entropy of activation $(\mathrm{J} / \mathrm{mol} \mathrm{K})$.

The enthalpy of activation, $\Delta \mathrm{H}$, was calculated using Eq. 7. The activation free energy, $\Delta G$ was calculated using Eq. 8 and the activation entropy, $\Delta S$ was determined according to Eq. 9. All terms were previously described in the equations above.

$\Delta \mathrm{H}=\mathrm{E}_{\mathrm{ad}}-\mathrm{RT}$

$\Delta \mathrm{G}=-\mathrm{RT} \ln \left(\frac{\mathrm{k}_{\mathrm{d}} \mathrm{h}}{\mathrm{k}_{\mathrm{b}} \mathrm{T}}\right)$

$\Delta \mathrm{S}=\frac{(\Delta \mathrm{H}-\Delta \mathrm{G})}{\mathrm{T}}$

Purification and characterization of purified protease

The protease of $B$. licheniformis LBA 46 strain was produced using the optimized conditions of temperature and agitation. The supernatant was separated by centrifugation and fractionated with $80 \%$ ammonium sulfate. The precipitate was dissolved in $0.05 \mathrm{M}$ phosphate buffer, $\mathrm{pH} 7$, and dialyzed against distilled water at $5{ }^{\circ} \mathrm{C}$ and freeze-dried. The freezedried protease was applied to a $20 \mathrm{mLDEAE}$-Sepharose ion exchange column (HiPrep ${ }^{\mathrm{TM}}$ DEAE FF 16/10, GE, Little Chalfont, UK) equilibrated with $0.05 \mathrm{M}$ sodium phosphate buffer, $\mathrm{pH} \mathrm{7,} \mathrm{and} \mathrm{the} \mathrm{proteins} \mathrm{were} \mathrm{eluted}$ $(5 \mathrm{~mL} / \mathrm{min})$ with a linear 0 to $1 \mathrm{M}$ sodium chloride gradient (Äkta Purifier, GE, Little Chalfont, UK). Fractions containing protease activity were pooled and analyzed by SDS-PAGE (Vertical Slab Mini-Protean Electrophoresis System, Bio-Rad Laboratories, Hercules, CA, USA) as described by Laemmli (1970). The run was performed at $110 \mathrm{~V}$ for $30 \mathrm{~min}$. The molecular weight of the enzyme was estimated using molecular mass markers (Thermo Fisher Scientific Ruler ${ }^{\mathrm{TM}}$ Unstained Protein Ladder) ranging from 10 to $200 \mathrm{kDa}$. Protein bands were visualized by staining with Coomassie Brilliant Blue R-250. 
Determination of the optimum $\mathrm{pH}$ of activity and stability of purified protease

The effect of $\mathrm{pH}$ on protease activity was determined by univariate assay using $0.1 \mathrm{M}$ acetate buffer $(\mathrm{pH}$ 4-5), $0.1 \mathrm{M}$ sodium phosphate buffer ( $\mathrm{pH}$ 6-8), $0.1 \mathrm{M}$ Tris- $\mathrm{HCl}$ buffer ( $\mathrm{pH}$ 9), 0.1 M carbonate-bicarbonate buffer ( $\mathrm{pH} \mathrm{10)}$ and $0.1 \mathrm{M} \mathrm{NaOH}$-bicarbonate buffer (pH 11).

The effect of $\mathrm{pH}$ on protease stability was determined using the same buffers and $\mathrm{pH}$ values already mentioned. The enzyme solutions were incubated at different $\mathrm{pH}$ values for $24 \mathrm{~h}$ at $4{ }^{\circ} \mathrm{C}$ in the absence of substrate. The residual enzyme activity was then determined. The results were expressed as a percentage and relative activity.

Determination of the optimum temperature of activity and stability of purified protease

The protease activity was tested at different temperatures (between $30^{\circ} \mathrm{C}$ and $80^{\circ} \mathrm{C}, \mathrm{pH} 7$ ). Relative activities were determined by defining the maximum enzyme activity, at a specific temperature, as $100 \%$.

The thermal stability of the enzyme was evaluated by preincubation at various temperatures (between 30 ${ }^{\circ} \mathrm{C}$ and $80^{\circ} \mathrm{C}, \mathrm{pH} 7$ ) for $1 \mathrm{~h}$ with subsequent cooling, and the residual enzymatic activity was determined.

\section{Statistical analysis}

The experimental design, matrix and statistical analysis were developed using the Statistica 7.0 program (Statsoft ${ }^{\circledR} /$ Dell, USA), Tukey's test and Pearson correlation were carried out in Minitab 16.1.1 (Minitab Inc., USA). All the analyses were carried out in triplicate and evaluated considering a $p$-value lower than $10 \%(p \leq 0.10)$.

\section{RESULTS AND DISCUSSION}

\section{Experimental design for the kinetics of protease production in a reactor}

Preliminary tests were performed to verify the effects of temperature (in the range of $30-37{ }^{\circ} \mathrm{C}$ ) on extracellular protease production by $B$. licheniformis LBA 46. Using $100 \mathrm{~mL}$ of culture medium in Erlenmeyer flasks, it was found that temperature variations caused variations in the protease production. Therefore, the reactor studies were carried out using the reactor in this temperature range. Figure 1 presents the responses obtained in the factorial design for the effect of temperature and agitation during the kinetics of protease production by $B$. licheniformis LBA 46 in a reactor for $72 \mathrm{~h}$ of fermentation.

The estimated enzymatic activity for the kinetics at $72 \mathrm{~h}$ (Figure 1A) showed that the values remained high ( $>1000 \mathrm{U} / \mathrm{mL})$ in $71.43 \%$ of the assays analyzed. Under the conditions evaluated, the microorganism produced protease in the range from $30-37^{\circ} \mathrm{C}$ and $200-$ $300 \mathrm{rpm}$.

It can be observed that, for the majority of the analyzed times, the central points (assays 5-7) and
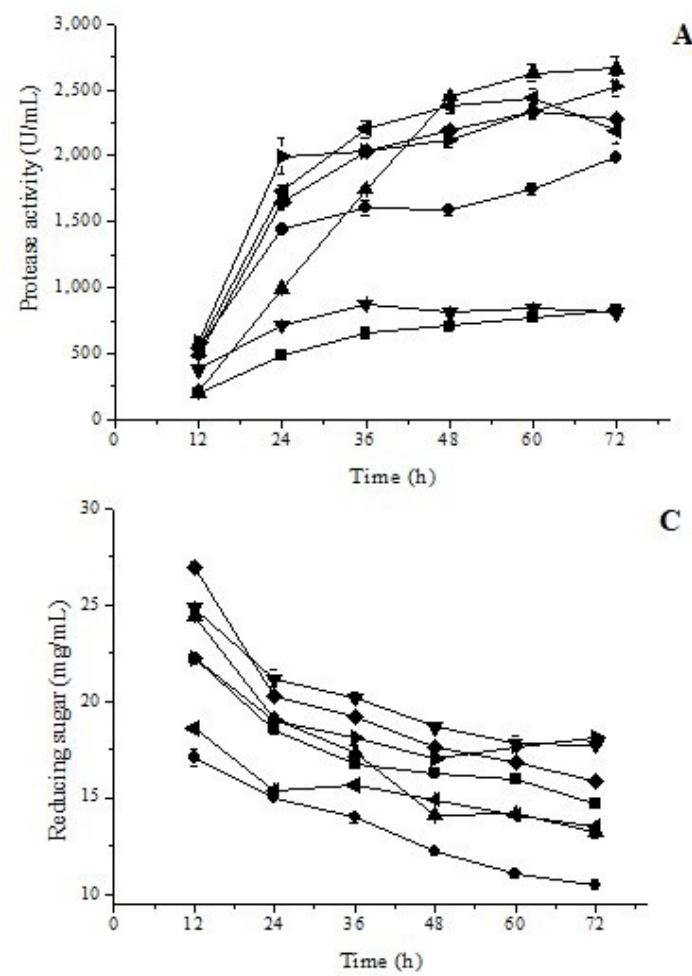

C
A
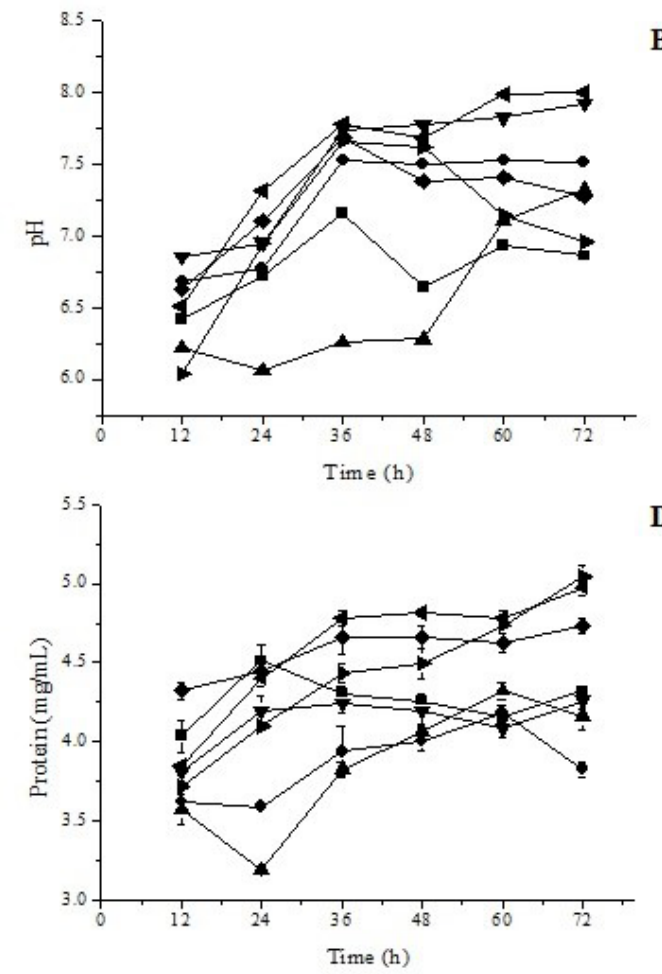

B

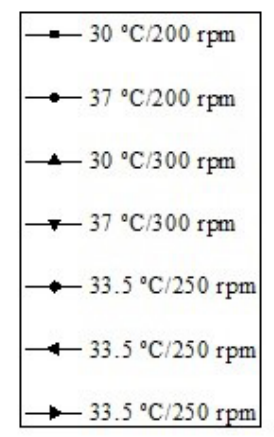

D

Figure 1. Kinetics of the protease production (A), $\mathrm{pH}$ values (B), reducing sugars (C) and protein (D) measured during fermentation of $B$. licheniformis LBA 46 in a bench reactor during $72 \mathrm{~h}$ of fermentation. 
assay 3 presented values of activity greater than the other tests. This information indicates that there is no adequate fit for a 1st order model, so there is a necessity of evaluating the curvature. According to the $p$-value obtained $(p \leq 0.10)$, the analysis of curvature was significant. Table 2 presents the estimated regression coefficients for each variable, their interaction and the statistical analysis of each effect for significance assessment.

For protease activity, the temperature, the agitation and the interaction between them showed effects on the factorial design, and the calculated $p$-value confirmed the presence of all significant effects after $48 \mathrm{~h}$ of fermentation with $90 \%$ of confidence (Table 2 ). The maximum protease activity was reached under the conditions of assay $3\left(30{ }^{\circ} \mathrm{C}\right.$ and $\left.300 \mathrm{rpm}\right)$, which presented activities of $2,448.83,2,627.33$ and

Table 2. Regression coefficients, standard error, $\mathrm{t}_{\text {calc }}$ and $p$-value during the protease production by $B$. licheniformis LBA 46 in a bench reactor during $72 \mathrm{~h}$ of fermentation.

\begin{tabular}{|c|c|c|c|c|}
\hline Variables & Coefficient & $\begin{array}{c}\text { Standard } \\
\text { error }\end{array}$ & $\mathbf{t}_{\text {calc }}$ * & $p$-value \\
\hline \multicolumn{5}{|c|}{$12 \mathrm{~h}$ of fermentation } \\
\hline Mean & 333.96 & 22.97 & 14.54 & 0.005 \\
\hline Curvature & 204.17 & 35.09 & 5.82 & 0.028 \\
\hline Temperature & 130.96 & 22.97 & 5.70 & 0.029 \\
\hline Agitation & -40.54 & 22.97 & -1.76 & 0.219 \\
\hline Interaction & -42.87 & 22.97 & -1.87 & 0.203 \\
\hline \multicolumn{5}{|c|}{$24 \mathrm{~h}$ of fermentation } \\
\hline Mean & 909.13 & 92.10 & 9.87 & 0.0101 \\
\hline Curvature & 884.43 & 140.69 & 6.29 & 0.0244 \\
\hline Temperature & 169.46 & 92.10 & 1.84 & 0.2072 \\
\hline Agitation & -53.38 & 92.10 & -0.58 & 0.6208 \\
\hline Interaction & -308.88 & 92.10 & -3.35 & 0.0786 \\
\hline \multicolumn{5}{|c|}{$36 \mathrm{~h}$ of fermentation } \\
\hline Mean & $1,221.50$ & 49.44 & 24.71 & 0.0016 \\
\hline Curvature & 868.19 & 75.52 & 11.50 & 0.0075 \\
\hline Temperature & 19.83 & 49.44 & 0.40 & 0.7271 \\
\hline Agitation & 88.67 & 49.44 & 1.79 & 0.2148 \\
\hline Interaction & -453.83 & 49.44 & -9.18 & 0.0117 \\
\hline \multicolumn{5}{|c|}{$48 \mathrm{~h}$ of fermentation } \\
\hline Mean & $1,301.13$ & 66.60 & 19.54 & 0.0026 \\
\hline Curvature & 926.53 & 101.73 & 9.11 & 0.0118 \\
\hline Temperature & -277.38 & 66.60 & -4.17 & 0.0531 \\
\hline Agitation & 329.29 & 66.60 & 4.94 & 0.0386 \\
\hline Interaction & -541.04 & 66.60 & -8.12 & 0.0148 \\
\hline \multicolumn{5}{|c|}{$60 \mathrm{~h}$ of fermentation } \\
\hline Mean & $1,499.17$ & 30.91 & 48.50 & 0.0004 \\
\hline Curvature & 871.31 & 47.21 & 18.45 & 0.0029 \\
\hline Temperature & -202.42 & 30.91 & -6.55 & 0.0225 \\
\hline Agitation & 235.67 & 30.91 & 7.62 & 0.0168 \\
\hline Interaction & -690.08 & 30.91 & -22.33 & 0.0020 \\
\hline \multicolumn{5}{|c|}{$72 \mathrm{~h}$ of fermentation } \\
\hline Mean & $1,571.21$ & 88.34 & 17.79 & 0.0031 \\
\hline Curvature & 761.35 & 134.95 & 5.64 & 0.0300 \\
\hline Temperature & -173.54 & 88.34 & -1.96 & 0.1884 \\
\hline Agitation & 163.63 & 88.34 & 1.85 & 0.2052 \\
\hline Interaction & -752.79 & 88.34 & -8.52 & 0.0135 \\
\hline
\end{tabular}

2,661.17 U/mL after 48, 60 and $72 \mathrm{~h}$ of fermentation, corresponding to protease productivity values equals to 51, 46.8 and 36.7 U/mL.h, respectively. The values for the coefficients of temperature and agitation from 48 $\mathrm{h}$ of fermentation were high, negative for temperature and positive for agitation, which means that, when the temperature decreased and the agitation increased, the protease activity was at its highest. The assay 3 fitted perfectly with these conditions, and it was chosen for the protease production.

Figure $1(\mathrm{~B}, \mathrm{C}, \mathrm{D})$ shows the $\mathrm{pH}$ values, reducing sugars and protein measured during fermentation by $B$. licheniformis LBA 46 in a reactor. The $\mathrm{pH}$ of the culture medium provides some important information. The initial $\mathrm{pH}$ (7) of the culture medium decreased to 6-6.8 after $12 \mathrm{~h}$ and then increased to reach 6.8-8 after $72 \mathrm{~h}$ in the most assays. The $\mathrm{pH}$ initially dropped, probably due to acid production from glucose utilization during the growth phase with the increase in the number of microbial cells, but when the enzymatic production was initiated, the pH started to increase (Singh et al., 2004). The culture medium used is a complex medium, which presents a variety of proteins and peptides from the yeast extract, dried whey protein and corn steep liquor. According to Chu et al. (1992), the acidification or alkalinization of the medium during the microbial growth reflects the substrate consumption. When microbial cells use organic nitrogen (amino acids and proteins), the medium becomes more alkaline, resulting in a $\mathrm{pH}$ increase, and when ammonium ion is used, the medium turns more acidic, resulting in a $\mathrm{pH}$ decrease.

Consumption of sugars and protein synthesis were consistent with cell growth. The sugars were consumed and decreased with the advance of the fermentation, the expected behavior, because the sugars are fermented by the microorganisms during their growth to supply their metabolic needs. According to Figure $1 \mathrm{C}$, the consumption of sugars had a similar profile for the 7 assays. Protein content of the culture medium increased in all assays, reaching about 3.5-5 mg/mL after $72 \mathrm{~h}$ of fermentation (Figure 1D), representing the increase in the protease production.

Dey et al. (2016) evaluated the improvement of protease production by $B$. licheniformis NCIM-2042 in a $2.2 \mathrm{~L}$ bioreactor containing $30.8 \mathrm{~g} / \mathrm{L}$ starch, 78.89 $\mathrm{g} / \mathrm{L}$ soybean meal, $0.5 \mathrm{~g} / \mathrm{L} \mathrm{MgSO}_{4}$, and $5.3 \mathrm{~g} / \mathrm{L} \mathrm{NaCl}$, $\mathrm{pH}$ 7.4. The effect of aeration (1,2 and $3 \mathrm{vvm})$ and agitation (150-210 rpm) were tested and the maximum protease production, $382.46 \mathrm{U} / \mathrm{mL}$, was achieved using $180 \mathrm{rpm}$ and $2 \mathrm{vvm}$, after $84 \mathrm{~h}$ of incubation at $37^{\circ} \mathrm{C}$. On the contrary, in this study a higher protease production $(>2400 \mathrm{U} / \mathrm{mL})$ was obtained after $48 \mathrm{~h}$ of fermentation using lower temperature and lower agitation than those used by Dey et al. (2016). 
Chuprom et al. (2016) studied the enhancement of halophilic protease production by Halobacterium sp. strain LBU50301 using statistical design response to optimize the medium composition. Using $18.62 \mathrm{~g} / \mathrm{L}$ gelatin, $9.13 \mathrm{~g} / \mathrm{L} \mathrm{MgSO} 4.7 \mathrm{H}_{2} \mathrm{O}, 27.95 \%$ (w/v) $\mathrm{NaCl}$, $\mathrm{pH} 7.88$ as culture medium the protease production increased 13-fold from $17.80 \mathrm{U} / \mathrm{mL}$ in Erlenmeyer flasks to $231.33 \mathrm{U} / \mathrm{mL}$ in a laboratory fermenter. According to the authors, the production of proteases obtained in the reactor was higher than that obtained in the fermentation of the Erlenmeyer flasks, since the reactor systems provide more precise control of parameters such as $\mathrm{pH}$, aeration and stirring speed. As in this work, Chuprom et al. (2016) also observed that the optimization tool is useful for increasing the enzymatic production, as well as the use of a reactor. However, the values of enzyme activity found in this study were higher than those mentioned above. The protease of $B$. licheniformis LBA 46 was produced in greater quantity $(>2400 \mathrm{U} / \mathrm{mL})$ when produced in a reactor with optimized conditions of temperature and agitation $\left(30^{\circ} \mathrm{C}\right.$ and $\left.300 \mathrm{rpm}\right)$. The strain of $B$. licheniformis LBA 46, in the conditions studied, was a better protease producer than the strain investigated by Chuprom et al. (2016).

Besides the activity values reported by Dey et al. (2016) and Chuprom et al. (2016) being lower than those found in this study, the culture medium used by them was synthetic, unlike the culture medium used in this work, which was composed of agro-industrial low-cost by-products.

\section{Kinetics of microbial growth and protease production}

In the fermentation of $B$. licheniformis LBA 46 in a $6 \mathrm{~L}$ reactor in the best conditions of temperature $\left(30^{\circ} \mathrm{C}\right)$ and agitation $(300 \mathrm{rpm})$, according to assay 3 , the protease was produced in the exponential phase of growth reaching maximum activity $(\sim 3,000 \mathrm{U} /$ $\mathrm{mL}$ ) after $48 \mathrm{~h}$ of fermentation. The reducing sugar content in the culture medium decreased to $17.9 \mathrm{mg} /$ $\mathrm{mL}$ and $16.2 \mathrm{mg} / \mathrm{mL}$ after 36 and $48 \mathrm{~h}$ of fermentation, respectively. Cell growth decreased after $48 \mathrm{~h}$ of fermentation (Figure 2).

The production of proteases by Bacillus species is controlled by a number of complex mechanisms that occur during the transition between exponential and stationary phases. The production of enzymes is related to the growth phase of the microorganism (Strauch and Hock, 1993). According to Strauch and Hock (1993), Jisha et al. (2013) and Contesini (2014), proteases from Bacillus sp. are mainly produced during the stationary phase of microbial growth. The extracellular enzyme production pattern depends on the Bacillus strains (Jisha et al., 2013).

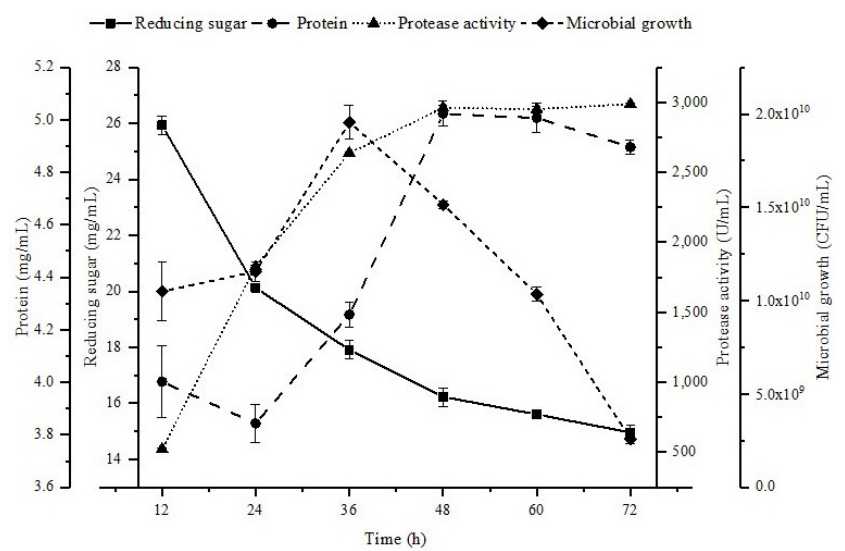

Figure 2. Fermentation of $B$. licheniformis LBA 46 in a bench reactor at temperature of $30{ }^{\circ} \mathrm{C}$ and agitation of $300 \mathrm{rpm}$ : microbial growth, protease production, reducing sugar and protein content.

The highest activity of protease from $B$. subtilis UO01 was reached after $15 \mathrm{~h}$ of fermentation $(10 \mathrm{U} / \mathrm{mL})$, when the microbial cells entered the post-exponential phase. This may occur due to the need for nutrients for microbial survival or due to the need for renewal of cell proteins at a lower growth rate. The enzyme production was associated with microbial growth (Blanco et al., 2016). Dias et al. (2008) observed maximum proteolytic activity of the enzyme produced by B. subtilis ATCC $6633(839.8 \mathrm{U} / \mathrm{mg})$ and Bacillus sp. UFLA 817 (975.9 U/mg) after $24 \mathrm{~h}$ of fermentation, coinciding with the end of the exponential phase of microbial growth. The protease production by Bacillus cereus VITSN04 also had its maximum activity (200 $\mathrm{U} / \mathrm{mL}$ ) associated with the exponential growth phase (Sundararajan et al., 2011).

The protease from Bacillus megaterium was produced in accordance with the bacterial growth. The maximum protease activity $(7 \mathrm{U} / \mathrm{mL})$ was achieved during the stationary phase after $15 \mathrm{~h}$ of fermentation (Uttatree et al., 2017). Rao e Narasu (2007) observed that the maximum activity $(215 \mathrm{U} / \mathrm{mL})$ of the protease produced by Bacillus firmus 7728 was reached in the stationary phase after $48 \mathrm{~h}$ of growth.

The results presented in this study showed a high production of protease and high productivity, with values higher than those found in the mentioned literature, regardless of the microbial growth phase or the strain used in the production.

Determination of the kinetic and thermodynamic parameters of semi-purified protease

Activation energy and $Q_{10}$ value

Figure 3 presents the protease activity at different temperatures $\left(30-80{ }^{\circ} \mathrm{C}\right)$. It can be observed that the semi-purified protease from $B$. licheniformis LBA 46 showed high activity between $55-65^{\circ} \mathrm{C}$, with the optimum value at 60 and $65^{\circ} \mathrm{C}$. 


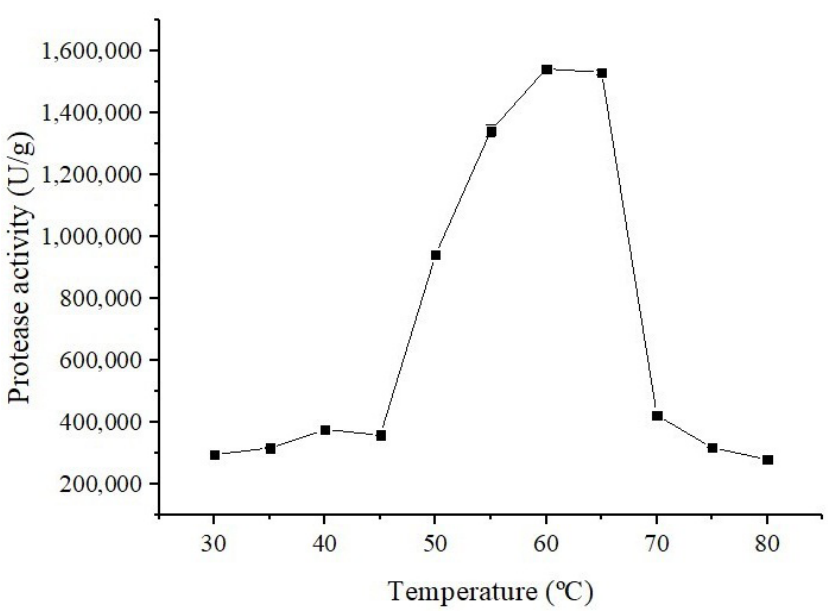

Figure 3. Effect of temperature on the activity of semipurified protease from B. licheniformis LBA 46.

For the range of temperature analyzed $\left(30-80{ }^{\circ} \mathrm{C}\right)$ a linear variation could be observed with the increase in temperature, which suggests that the protease has a single conformation at the temperature of transition (Castro et al. 2014).

The $E_{a}$ value $(47.96 \mathrm{~kJ} / \mathrm{mol})$ was high, positive and showed good correlation $\left(R^{2}=0.95\right)$, within the temperature range studied. Abdel-Naby (2017) described a lower $E_{a}$ of $17.31 \mathrm{~kJ} / \mathrm{mol}$ for alkaline protease from Bacillus stearothermophilus. Souza et al. (2015) also found $E_{a}(19.03 \mathrm{~kJ} / \mathrm{mol})$ for acid protease from Aspergillus foetidus lower than that described in this study. It can be observed that the proteases produced by different microorganisms have different $E_{a}$ values. As related in this study, an alkaline protease from Nacordiopsis alba showed a high $E_{a}$ value of $36.80 \mathrm{~kJ} / \mathrm{mol}$ (Gohel and Singh, 2012). The high reported values mean that to make the activated enzyme-substrate complex, more energy is required.

The $Q_{10}$ value is a kinetic parameter used to determine whether the catalytic reactions are controlled by temperature or other factors. According to Elias et al. (2014), the enzymatic reactions have values of $Q_{10}$ ranging from 1 to 2 . Values outside this range can be interpreted as indicative of the involvement of factors other than temperature in the control of the reaction rate. The $Q_{10}$ value was determined to be in the range of 1.59-1.87, representing the rate of reaction which was affected only by a temperature increase.

\section{Kinetic parameters, $K_{m}$ and $V_{\max }$}

The kinetic parameters were calculated according to a double reciprocal Lineweaver-Burk plot. The $K_{m}$ value indicates the protease-substrate affinity and a low $K_{m}$ value indicates higher affinity of the enzyme for the substrate. The $V_{\max }$ value could be defined as the maximum value of initial velocity when all actives sites are occupied by the substrate.
The enzyme showed, with good correlation $\left(R^{2}=0.91\right)$, Michaelis-Menten-type kinetics with $K_{m}$ $=1.60 \mathrm{mg} / \mathrm{mL}$ and a high $V_{\max }=2 \times 10^{6} \mathrm{U} / \mathrm{g}$. A similar $K_{m}$ value $(1.92 \mathrm{mg} / \mathrm{mL})$ was reported by Souza et al. (2015) for acid protease from A. foetidus utilizing azocasein as substrate. A lower $K_{m}$ value $(0.44 \mathrm{mg} /$ $\mathrm{mL}$ ) was related for serine protease from Aspergillus niger (Castro et al., 2014) also using azocasein as substrate. Using casein as substrate, Abdel-Naby (2017) determined a higher $K_{m}$ value $(3.7 \mathrm{mg} / \mathrm{mL})$ than the one found in this study for alkaline protease from $B$. stearothermophilus. It can be seen that the $K_{m}$ value depends on the type of substrate evaluated and the enzyme-producing microorganism.

\section{Thermal inactivation of semi-purified protease}

The thermostability of semi-purified protease from $B$. licheniformis LBA 46 was studied in the range of $50-70{ }^{\circ} \mathrm{C}$. The enzyme showed higher stability at a temperature of $50{ }^{\circ} \mathrm{C}$, retaining above $80 \%$ of the initial activity after $120 \mathrm{~min}$. The protease was rapidly inactivated at $70{ }^{\circ} \mathrm{C}$ in the absence of substrate, losing $84 \%$ of the initial activity after 30 min of incubation.

The half-life of an enzyme is defined as the amount of time required at a given temperature, capable of reducing its initial activity by half. According to Table 3, the semi-purified protease of $B$. licheniformis LBA 46 has high thermal resistance, requiring $693.15 \mathrm{~min}$ to reduce half of its activity at $50^{\circ} \mathrm{C}$ and that value fell as the temperature increased, reaching $23.90 \mathrm{~min}$ at $70{ }^{\circ} \mathrm{C}$. The $D$-value, which is the time required for a $90 \%$ reduction in the initial enzyme activity was also reduced with increasing temperature, ranging from 2,302.60 to $79.40 \mathrm{~min}$ between 50 and $70{ }^{\circ} \mathrm{C}$. In relation to the inactivation rate constants $\left(K_{d}\right)$, the values increased with an increase in temperature, ranging from $1.0 \times 10^{-3}$ to $29 \times 10^{-3} \mathrm{~min}^{-1}$. The energy required for thermal inactivation $(144.50 \mathrm{~kJ} / \mathrm{mol})$ was calculated using an Arrenius plot. Abdel-Naby (2017) determined a similar value for $E_{a}(105.5 \mathrm{~kJ} / \mathrm{mol})$ by studying an alkaline protease from $B$. stearothermophilus, which means that both enzymes require a similar amount of energy to be inactivated.

Table 3. Thermodynamic and kinetic parameters for thermal inactivation of semi-purified protease from $B$. licheniformis LBA 46.

\begin{tabular}{cccccc}
\hline $\begin{array}{c}\mathbf{T} \\
\left({ }^{\mathbf{C}} \mathbf{C}\right)\end{array}$ & $\begin{array}{c}\boldsymbol{k}_{\boldsymbol{d}} \\
\left(\mathbf{m i n}^{-1}\right)\end{array}$ & $\begin{array}{c}\boldsymbol{t}_{1 / 2} \\
(\mathbf{m i n})\end{array}$ & $\begin{array}{c}\boldsymbol{D} \\
(\mathbf{m i n})\end{array}$ & $\boldsymbol{R}^{2}$ & $\begin{array}{c}\boldsymbol{E}_{\boldsymbol{a d}} \\
(\mathbf{k J} / \mathbf{m o l})\end{array}$ \\
\hline 50 & 0.0010 & 693.15 & $2,302.60$ & 0.87 & \\
55 & 0.0030 & 231.05 & 767.53 & 0.93 & \\
60 & 0.0070 & 99.02 & 328.94 & 0.82 & 144.50 \\
65 & 0.0090 & 77.02 & 255.84 & 0.90 & \\
70 & 0.0290 & 23.90 & 79.40 & 0.96 & \\
\hline
\end{tabular}


Thermal inactivation of enzymes is accompanied by the breakdown of many non-covalent bonds, which represents an increase in the value of $\Delta \mathrm{H}$. According to Batista et al. (2014), high $\Delta \mathrm{H}$ values are linked to high thermal stability of the enzyme. The opening or unfolding of the enzyme caused by heating increases its disordered state, which can be measured by the value of $\Delta \mathrm{S}$. An enzymatic reaction can also be evaluated by measuring the change in $\Delta \mathrm{G}$ value during the conversion of an enzyme-substrate complex into a product (Riaz et al., 2007). A low $\Delta \mathrm{G}$ value suggests that this conversion is more spontaneous; however, high $\Delta \mathrm{G}$ values indicate high enzyme stability (Batista et al., 2014).

The values of $\Delta \mathrm{H}, \Delta \mathrm{S}$ and $\Delta \mathrm{G}$ practically did not vary within the temperatures analyzed (Table 4 ), in this case, these temperatures were not capable of causing visible changes in the enzymatic behavior, which remained constant within the range of temperature evaluated. The parameters of kinetic inactivation are important since they serve to define and model the use of enzymes in certain industrial applications.

Table 4. Thermodynamic parameters for thermal inactivation of semi-purified protease from $B$. licheniformis LBA 46.

\begin{tabular}{cccc}
\hline $\mathbf{T}$ & $\mathbf{\Delta H}$ & $\mathbf{\Delta S}$ & $\Delta \mathbf{G}$ \\
$\mathbf{(} \mathbf{C})$ & $(\mathbf{k J} / \mathbf{m o l})$ & $(\mathbf{J} / \mathbf{m o l . K})$ & $(\mathbf{k J} / \mathbf{m o l})$ \\
\hline 50 & 141.81 & 101.79 & 108.92 \\
55 & 141.77 & 103.98 & 107.65 \\
60 & 141.73 & 104.28 & 106.99 \\
65 & 141.69 & 99.83 & 107.93 \\
70 & 141.65 & 103.21 & 106.23 \\
\hline
\end{tabular}

\section{Purification of protease}

The protease from $B$. licheniformis LBA 46 was purified 3.33 fold using $80 \%$ ammonium sulfate precipitation and using DEAE-Sepharose column chromatography. The purified protease showed a specific activity of $628.96 \mathrm{U} / \mathrm{mg}$ (Table 5).

\section{Biochemical characterization of purified protease}

The molecular weight of purified protease from B. licheniformis LBA 46 was estimated as $40 \mathrm{kDa}$ by SDS-PAGE (Figure 4).

Jalkute et al. (2017) purified the protease from Bacillus safensis CK about 7-fold by DEAEcellulose column chromatography and estimated the

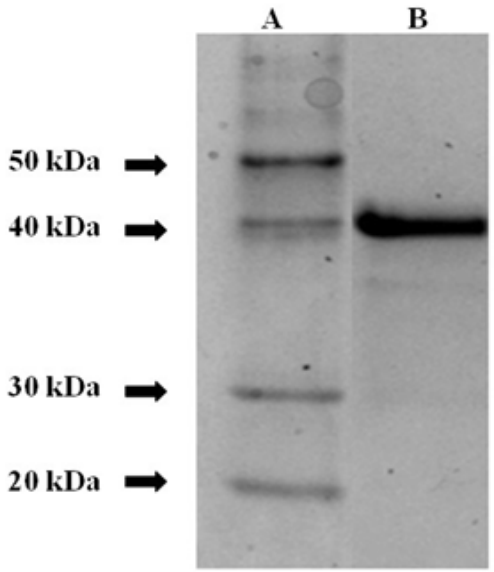

Figure 4. SDS-PAGE of purified protease from $B$. licheniformis LBA 46. (A) molecular mass markers and (B) purified protease.

molecular weight (equal to that found in this study) of the protease at $40 \mathrm{kDa}$ by SDS-PAGE. Other works have studied different types of proteases from Bacillus sp. purification using various methods with varied molecular weights. Annamalai et al. (2013) purified a $33 \mathrm{kDa}$ protease from Bacillus alveayuensis CAS 5 using DEAE-cellulose and Sephadex G-50 columns. Jellouli et al. (2011) purified a $30 \mathrm{kDa}$ protease from $B$. licheniformis MP1 using Sephadex G-100 and Mono Q-Sepharose columns. Lakshmi et al. (2018) purified a protease from Bacillus cereus strain S8 using ion exchange followed by gel filtration chromatography. The estimated molecular weight was $21.8 \mathrm{kDa}$. As in this work, several studies in the literature also described proteases with low molecular weight from Bacillus sp.: $15 \mathrm{kDa}$ (Adinarayana et al. 2003), $17.10 \mathrm{kDa}$ (Kim and Kim 2005), 20.10 kDa (Rai et al. 2009), $30 \mathrm{kDa}$ (Hadjidj et al., 2018).

The purified protease of $B$. licheniformis LBA 46 presented high activity $(>80 \%)$ in the range of $\mathrm{pH}$ $6.5-9$, optimal activity at $\mathrm{pH} 8.5$ and low activity at $\mathrm{pH} 4.0(15 \%)$. The purified protease was stable in the range of $\mathrm{pH} 5-10$ after $24 \mathrm{~h}$ at $4{ }^{\circ} \mathrm{C}$, retaining more than $86 \%$ of the initial activity (Figure $5 \mathrm{~A}$ ). The purified protease presented optimum activity at 50 and $60{ }^{\circ} \mathrm{Cat} \mathrm{pH} 7.0$. The enzyme was stable at 40 ${ }^{\circ} \mathrm{C}$ for $1 \mathrm{~h}$ in $\mathrm{pH} 7$ and retained $85 \%$ of the initial activity after $1 \mathrm{~h}$ of treatment at $50^{\circ} \mathrm{C}, \mathrm{pH} 7$ (Figure 5B).

Table 5. Summary purification of protease from $B$. licheniformis LBA 46.

\begin{tabular}{cccccc}
\hline Purification step & Total activity & Total protein & $\begin{array}{c}\text { Specific activity } \\
(\mathbf{U} / \mathbf{m g})\end{array}$ & $\begin{array}{c}\text { Recovery } \\
(\mathbf{\%})\end{array}$ & $\begin{array}{c}\text { Purification } \\
\text { fold }\end{array}$ \\
\hline Crude extract & $6,355,416.67$ & $33,620.33$ & 189.03 & 100 & 1 \\
Ammonium sulfate precipitation & $539,933.33$ & $4,300.32$ & 125.56 & 8.50 & 0.66 \\
DEAE-Sepharose & 327.90 & 0.52 & 628.96 & 0.005 & 3.33 \\
\hline
\end{tabular}



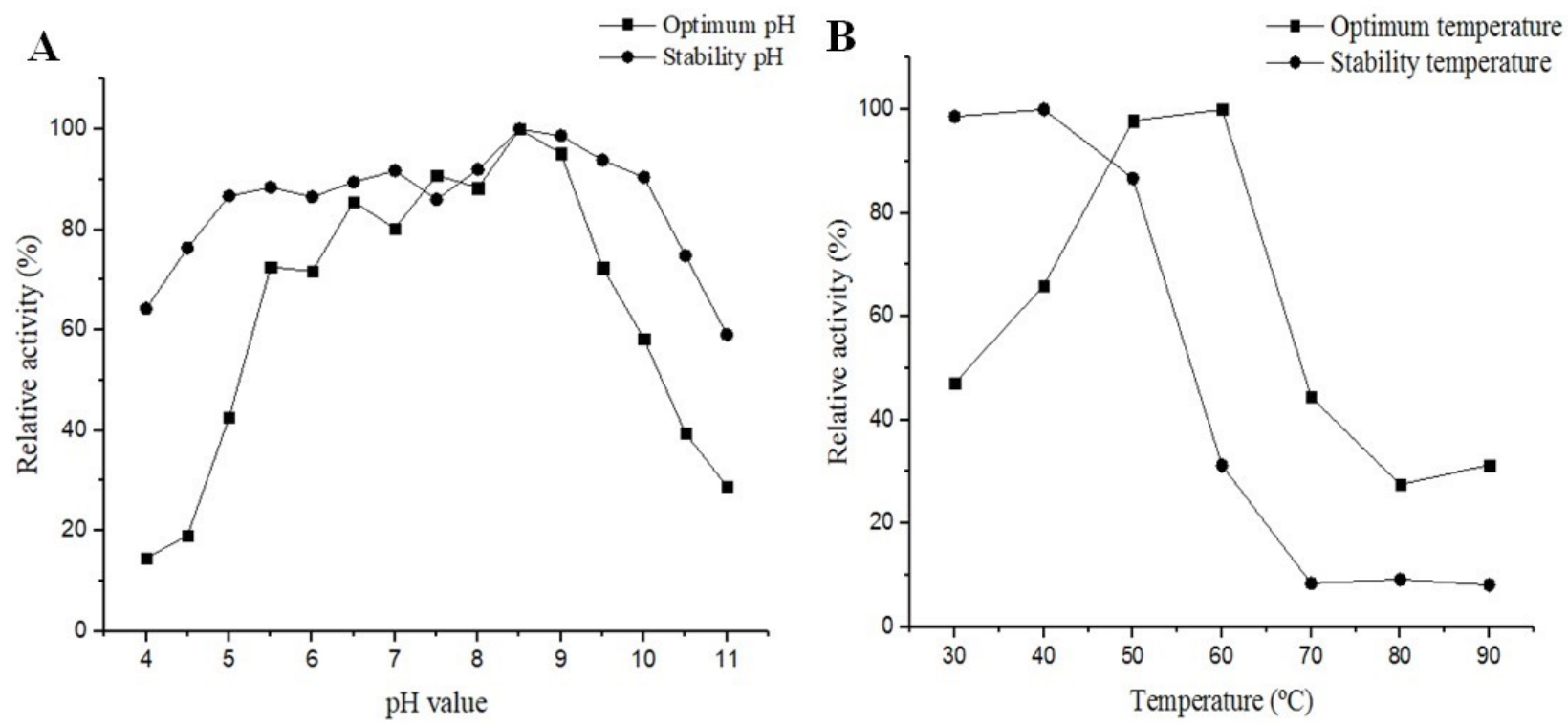

Figure 5. Optimum and stability $\mathrm{pH}(\mathrm{A})$ and temperature (B) of purified protease from B. licheniformis LBA 46.

\section{CONCLUSIONS}

A protease from $B$. licheniformis LBA 46 was produced using agroindustrial by-products as sources of carbon and nitrogen in a reactor. The highest protease activity was obtained after $48 \mathrm{~h}$ of fermentation at $30^{\circ} \mathrm{C}$ and $300 \mathrm{rpm}$. The semi-purified protease showed high catalytic activity $(\sim 1,500,000$ $\mathrm{U} / \mathrm{g}$ ) with an optimum at 60 and $65^{\circ} \mathrm{C}$. The purified protease presented optimum activity at 50 and $60{ }^{\circ} \mathrm{C}$ and was stable in the range of $\mathrm{pH} 5-10$ after $24 \mathrm{~h}$ at 4 ${ }^{\circ} \mathrm{C}$. This protease presented interesting characteristics for potential industrial application.

\section{ACKNOWLEDGMENTS}

The authors are grateful to Alibra ${ }^{\circledR}$ and Corn Products Brasil ${ }^{\circledR}$ for kindly providing the dried whey and corn steep liquor, respectively.

\section{REFERENCES}

Abdel-Naby, M.A., Ahmed, S.A., Wehaidy, H.R., Elmahdy, S.A. Catalytic, kinetic and thermodynamic properties of stabilized Bacillus stearothermophilus alkaline protease. International Journal of Biological Macromolecules, 96, 265-271 (2017). https://doi.org/10.1016/j.ijbiomac.2016.11.094

Adinarayana, K., Ellaiah, P., Prasad, D.S. Purification and partial characterization of thermostable serine alkaline protease from a newly isolated Bacillus subtilis PE-11. The American Association of Pharmaceutical Scientists, 4, 440-448 (2003). https://doi.org/10.1208/pt040456

Annamalai, N., Rajeswari, M.V., Balasubramanian, T. Extraction, purification and application of thermostable and halostable alkaline protease from
Bacillus alveayuensis CAS 5 using marine wastes. Food and Bioproducts Processing, 92, 335-342 (2013). https://doi.org/10.1016/j.fbp.2013.08.009

Batista, K.A., Batista, G.L.A., Alves, G.L., Fernandes, K.F. Extraction, partial purification and characterization of polyphenol oxidase from Solanum lycocarpum fruits. Journal of Molecular Catalysis B: Enzymatic, 102, 211-217 (2014). https://doi.org/10.1016/j.molcatb.2014.02.017

Benmrad, M.O., Moujehed, E., Ben Elhoul, M., Zarâ̂ Jaouadi, N., Mechri, S., Rekik, H., Kourdali, S., El Hattab, M., Badis, A., Sayadi, S., Bejar, S., Jaouadi, B. A novel organic solvent- and detergentstable serine alkaline protease from Trametes cingulata strain CTM10101. International Journal of Biological Macromolecules, 91, 961-972 (2016). https://doi.org/10.1016/j.ijbiomac.2016.06.025

Blanco, A.S., Durive, O.P., Pérez, S.B., Montez, Z.D., Guerra, N.P. Simultaneous production of amylases and proteases by Bacillus subtilis in brewery wastes. Brazilian Journal of Microbiology, 47, 665-74 (2016). https://doi.org/10.1016/j.bjm.2016.04.019

Bouacem, K., Bouanane-Darenfed, A., Zaraî Jaouadi, N., Joseph, M., Hacene, H., Ollivier, B., Fardeau, M.L., Bejar, S., Jaouadi, B. Novel serine keratinase from Caldicoprobacter algeriensis exhibiting outstanding hide dehairing abilities. International Journal of Biological Macromolecules, 86, 321-328 (2016). https://doi.org/10.1016/j. ijbiomac.2016.01.074

Castro, R.J.S., Sato, H.H. Advantages of an acid protease from Aspergillus oryzae over commercial preparations for production of whey protein hydrolysates with antioxidant activities. Biocatalysis and Agricultural Biotechnology, 3, 58-65 (2014). https://doi.org/10.1016/j. bcab.2013.11.012 
Castro, R.J.S., Ohara, A., Nishide, T.G., Albernaz, J.R.M., Soares, M.H., Sato, H.H. A new approach for proteases production by Aspergillus niger based on the kinetic and thermodynamic parameters of the enzymes obtained. Biocatalysis and Agricultural Biotechnology, 4, 199-207 (2014). https://doi. org/10.1016/j.bcab.2014.12.001

Charney, J., Tomarelli, R.M. A colorimetric method for the determination of the proteolytic activity of duodenal juice. The Journal of Biological Chemistry, 170, 501-505 (1947).

Chu, I.-M., Lee, C., Li, T.-S. Production and degradation of alkaline protease in batch cultures of Bacillus subtilis ATCC 14416. Enzyme and Microbial Technology, 14, 55-761 (1992). https:// doi.org/10.1016/0141-0229(92)90116-6

Chuprom, J., Bovornreungroj, P., Ahmad, M., Kantachote, D., Dueramae, S. Approach toward enhancement of halophilic protease production by Halobacterium sp. strain LBU50301 using statistical design response surface methodology. Biotechnology Reports, 10, 17-28 (2016). https:// doi.org/10.1016/j.btre.2016.02.004

Contesini, F.J. Production, characterization and application of proteases from Bacillus sp. Ph.D. Thesis, University of Campinas (2014).

Dey, A., Bhunia, B., Dutta, S. Studies on the effect of agitation and aeration for the improved protease production by Bacillus licheniformis NCIM-2042. Materials Today: Proceedings, 3, 3444-3449 (2016). https://doi.org/10.1016/j.matpr.2016.10.026

Dias, D.R., Vilela, D.M., Silvestre, M.P.C., Schwan, R.F. Alkaline protease from Bacillus sp. isolated from coffee bean grown on cheese whey. World Journal of Microbiology and Biotechnology, 24, 2027-2034 (2008). https://doi.org/10.1007/s11274008-9706-6

Dixon, M., Webb, E.C. Enzyme Kinetics, third ed. Academic Press, New York (1979).

Elias, M., Wieczorek, G., Rosenne, S., Tawfik, D.S. The universality of enzymatic rate-temperature dependency. Trends in Biochemical Sciences, 39, 1-7 (2014). https://doi.org/10.1016/j. tibs.2013.11.001

Furhan, J., Sharma, S. Microbial alkaline proteases: Findings. International Journal of Pharmaceutical Science Invention, 2, 823-834 (2014).

Gohel, S.D., Singh, S.P. Purification strategies, characteristics and thermodynamic analysis of a highly thermostable alkaline protease from a salttolerant alkaliphilic actinomycete, Nocardiopsis alba OK-5. Journal of Chromatography. B, Analytical Technologies in the Biomedical and Life Sciences, 15, 61-68 (2012). https://doi. org/10.1016/j.jchromb.2012.01.031
Gupta, R., Beg, Q.K., Lorenz, P. Bacterial alkaline proteases: Molecular approaches and industrial applications. Applied Microbiology Biotechnology, 59, 15-32 (2002). https://doi.org/10.1007/s00253002-0975-y

Hadjidj, R., Badis, A., Mechri, S., Eddouaouda, K., Khelouia, L., Annane, R., Hattab, M., Jaouadi, B. Purification, biochemical, and molecular characterization of novel protease from Bacillus licheniformis strain K7A. International Journal of Biological Macromolecules, 114, 1033-1048(2018). https://doi.org/10.1016/j.ijbiomac.2018.03.167

Hartree, E.F. Determination of protein: A modification of the Lowry methods that gives a linear photometric response. Analytical Biochemistry, 48, 422-427 (1972). https://doi.org/10.1016/00032697(72)90094-2

Jalkute, C.B., Waghmare, S.R., Nadaf, N.H., Dhanavade, M.J., Jadhav, D.B., Pendhari, S.I., Patil, R.S., Sonawane, K.D. Purification and characterization of SDS stable protease from Bacillus safensis strain CK. Biocatalysis and Agricultural Biotechnology, 10, 91-95 (2017). https://doi.org/10.1016/j.bcab.2017.02.012

Jellouli, K., Ghorbel-Bellaaj, O., Ayed, H.B., Manni, L., Agrebi, R., Nasri, M. Alkaline-protease from Bacillus licheniformis MP1: purification, characterization and potential application as a detergent additive and for shrimp waste deproteinization. Process Biochemistry, 46, 1248-1256 (2011). https://doi.org/10.1016/j. procbio.2011.02.012

Jisha, V.N., Smitha, R.B., Pradeep, S., Sreedevi, S., Unni, K.N., Sajith, S., Priji, P., Josh, M.S., Benjamin, S. Versatility of microbial proteases. Advances in Enzyme Research, 1, 39-51 (2013). https://doi.org/10.4236/aer.2013.13005

Kim, W. J., Kim, S.M. Purification and characterization of Bacillus subtilis JM-3 protease from anchovy sauce. Journal of Food Biochemistry, 29, 591$610 \quad$ (2005). https://doi.org/10.1111/j.17454514.2005.00041.x

Laemmli, U. Cleavage of structural proteins during the assembly of the head of Bacteriophage T4. Nature, 227, 680-685 (1970). https://doi. org/10.1038/227680a0

Lakshmi, B.K.M, Kumar, D.M., Hemalatha, K.P.J. Purification and characterization of alkaline protease with novel properties from Bacillus cereus strain S8. Journal of Genetic Engineering and Biotechnology, 16, 295-304 (2018). https://doi. org/10.1016/j.jgeb.2018.05.009

Miller, G.L. Use of dinitrosalicylic acid reagent for determination of reducing sugar. Analytical Chemistry, 31, 426-428 (1959). https://doi. org/10.1021/ac60147a030 
Moo-Young, M., Chisti, Y. Biochemical engineering in biotechnology. Pure and Applied Chemistry, 66, 117-136 (1994). https://doi.org/10.1351/ pac199466010117

Pant, G., Prakash, A., Pavani, J.V.P., Bera, S., Deviram, G.V.N.S., Kumar, A., Panchpuri, M., Prasuna, R.G. Production, optimization and partial purification of protease from Bacillus subtilis. Journal of Taibah University for Science, 9, 50-55 (2015). https://doi. org/10.1016/j.jtusci.2014.04.010

Parrado, J., Rodriguez-Morgado, B., Tejada, M., Hernandez, T., Garcia, C. Proteomic analysis of enzyme production by Bacillus licheniformis using different feather wastes as the sole fermentation media. Enzyme and Microbial Technology, 57, 1-7 (2014). https://doi.org/10.1016/j. enzmictec.2014.01.001

Potumarthi, R., Ch, S., Jetty, A. Alkaline protease production by submerged fermentation in stirred tank reactor using Bacillus licheniformis NCIM2042: Effect of aeration and agitation regimes. Biochemical Engineering Journal, 34, 185-192 (2007). https://doi.org/10.1016/j.bej.2006.12.003

Rai, S.K., Konwarh, R., Mukherjee, A.K. Purification, characterization and biotechnological application of an alkaline $\beta$-keratinase produced by Bacillus subtilis RM-01 in solid-state fermentation using chicken-feather as substrate. Biochemical Engineering Journal, 45, 218-225 (2009). https://doi.org/10.1016/j.bej.2009.04.001

Rao, K., Narasu, M.L. Alkaline protease from Bacillus firmus 7728. African Journal of Biotechnology, 6, 2493-2496 (2007). https://doi.org/10.5897/ AJB2007.000-2395

Riaz, M., Perveen, R., Javed, M.R., Nadeem,H., Rashid, M.H. Kinetic and thermodynamic properties of novel glucoamylase from Humicola sp. Enzyme and Microbial Technology, 41, 558-564 (2007). https://doi.org/10.1016/j.enzmictec.2007.05.010
Schallmey, M., Singh, A., Ward, O.P. Developments in the use of Bacillus species for industrial production. Canadian Journal of Microbiology, 50, 1-17 (2004). https://doi.org/10.1139/w03-076

Souza, P.M., Aliakbarian, B., Ferreira Filho, E.X., Magalhães, O.P., Pessoa Junior, A., Converti, A., Perego, P. Kinetic and thermodynamic studies of a novel acid protease from Aspergillus foetidus. International Journal of Biological Macromolecules, 81, 17-21 (2015). https://doi. org/10.1016/j.ijbiomac.2015.07.043

Strauch, M.A., Hoch, J.A. Transition-state regulators: Sentinels of Bacillus subtilis post-exponential gene expression. Molecular Microbiology, 7, 337-342 (1993). https://doi.org/10.1111/j.1365-2958.1993. tb01125.x

Sundararajan, S., Kannan, C. N., Chittibabu, S. Alkaline protease from Bacillus cereus VITSN04: Potential application as a dehairing agent. Journal of Bioscience and Bioengineering, 111， 128-133 (2011). https://doi.org/10.1016/j. jbiosc.2010.09.009

Uttatree, S., Kobtrakool, K., Ketsuk, A., Kaenngam, W., Thakolprajak, P., Charoenpanich, J. A novel metaltolerant, solvent and surfactant stable protease from a new strain of Bacillus megaterium. Biocatalysis and Agricultural Biotechnology, 12, 228-235 (2017). https://doi.org/10.1016/j.bcab.2017.10.012

Voigt, B., Scheweder, T., Becher, D. A proteomic view of cell physiology of Bacillus licheniformis. Proteomics, 4, 1465-1490 (2004). https://doi. org/10.1002/pmic.200300684

Ward, O.P. Proteases, in: Moo-Young, M. (Ed.), Comprehensive Biotechnology. Elsevier, Waterloo, pp. 571-582 (2011). https://doi.org/10.1016/B9780-08-088504-9.00222-1

Ward, O.P., Rao, M.B., Kulkarni, A. Proteases, in: Schaechter, M. (Ed.), Encyclopedia of Microbiology, Amsterdam: Elsevier, pp. 495-511 (2009). https:// doi.org/10.1016/B978-012373944-5.00172-3 
